\title{
High Sensitivity C-Reactive Protein an inflammatory marker and lipoprotein levels in patients with coronary heart disease
}

\author{
Sindu P.C. ${ }^{1}$ \\ ${ }^{2}$ Dr. Sindu. PC, Professor, Department of Biochemistry, Amala Institute of Medical Sciences, Thrissur, Kerala, \\ India
}

Address for correspondence: Dr. Sindu P C, Email: drsindupc72@gmail.com

\begin{abstract}
Background: C-Reactive Protein is a good marker of systemic inflammation which can be measured easily. Atherosclerosis lesions are intimal thickening of arteries. Inflammatory and immune cells constitute an important part of atheroma. C-RP levels at the upper end of the normal range indicate that a low level of inflammatory response has been initiated. Measurment of hs CRP provides a method to assess the risk of cardiovascular disease very early in life. Aim: Estimation of High sensitivity C-Reactive Protein (HS-CRP) levels which is a marker of inflammation in serum of normal people and patients with past history of myocardial infarction. Materials and Methods: Twenty six serum samples from patients with coronary heart disease (who had previous history of Myocardial Infarction) and twenty-one control samples and were included in the study. High sensitivity C-reactive protein and lipoprotein profile were estimated in patients with coronary heart disease and in age matched controls. Statistical Analysis- All data were represented as mean \pm SD. Experimental data were statistically analyzed by students $t$ '-test. For all analysis statistical significance was considered as $\mathrm{p}<0.05$. Results: Mean hs C-RP level is significantly elevated in patients who had myocardial infarction when compared with age matched controls. Total cholesterol, LDL cholesterol also found to be increased in individuals who had myocardial infarction. Conclusion: Inflammation plays an important role in myocardial infarction. Increased risk of MI is seen in those individuals who have higher levels of hsC-RP. There is also increase in total cholesterol and LDL cholesterol in subjects who had myocardial infarction when compared to controls. Coronary artery disease may be prevented by reducing the inflammation in addition to reducing the LDL cholesterol.
\end{abstract}

Key words: Inflammation, C-reactive protein, atherosclerosis, myocardial infarction, serum cholesterol

\section{Introduction}

Acute phase reactants are the proteins whose plasma concentration increases when there is an inflammatory state such as infection, surgery, trauma, Myocardial Infarction, malignancy or in any condition associated with tissue necrosis. Changes in plasma proteins are referred as acute phase response. These acute phase proteins are secreted in response to cytokines produced by inflammatory cells. Cytokines interleukin-6 (IL-6) and TNF $-\alpha$ induce synthesis of $\mathrm{C}$ reactive protein $(\mathrm{C}$ $\mathrm{RP}) \mathrm{C}-\mathrm{RP}$ is produced by the liver and smooth muscle cells of coronary arteries in response to inflammatory stimuli. hsCRP is the most extensively studied and

Manuscript received: $25^{\text {th }} \mathrm{Feb} 2016$

Reviewed: $05^{\text {th }}$ March 2016

Author Corrected: $14^{\text {th }}$ March 2016

Accepted for Publication: $26^{\text {th }}$ March 2016 validated marker of vascular inflammation[1]. The lower levels of below $15 \mathrm{mg} / \mathrm{L}$ can be estimated by immunoturbidimetry. Atherosclerosis lesions are intimal thickening of arteries. Systemic inflammatory processes are taking place in atherosclerosis because there are increased concentrations of acute phase proteins, cytokines and cell adhesion molecules [2]. The lesions consist of cell, connective tissue elements and tissue debris. Inflammatory and immune cells constitute an important part of atheroma. $\mathrm{T}$ cell cytokines stimulate the formation of number of molecules downstream in the cytokine cascade. These include interferon, interleukin-1, TNF- $\alpha$ and interleukin-6 [3]. Of these, interleukin- 6 and C-RP are found to be particularly elevated in patients with unstable angina 
and myocardial infarction, with high levels predicting worst prognosis $[4,5]$. The elevated C-reactive protein in myocardial infarction reflects the inflammation in the coronary artery rather than ischemic myocardium. C reactive protein is not elevated in patients with angina due to vasospasm [6].

Inflammatory process plays an early as well as late role in the development of atherosclerosis [7]. Elevated C$\mathrm{RP}$ indicates an inflammatory response. C-RP levels at the upper end of the normal range indicate that a low level of inflammatory response has been initiated. These levels, when they are persistent in apparently healthy individuals, indicate an increased risk of cardiovascular disease and stroke. Measurment of hs CRP provides a method to assess the risk of cardiovascular disease very early in life.

hsC-RP is considered to be an important predictive marker in the clinical setting for several reasons. It can be estimated by a non invasive, inexpensive, standardized high sensitivity commercial assay. In addition to lipid profile and Framingham Cardiovascular Risk Score additional information is obtained from levels of hs C-RP. [8,9,10]. Guidelines proposed by the American Heart Association and the Centers for Disease Control and Prevention on the use of hsC-RP in the clinical setting suggest measuring hsC-RPlevels in addition to lipid levels in those who have intermediate risk for coronary heart disease[1].

hsC-RP has been used as a predictive marker for atherosclerosis. The level of hsCRP is between 0 and $1 \mathrm{mg} / \mathrm{L}$ is low risk, the levels between 1 and $3 \mathrm{mg} / \mathrm{L}$ is intermediate risk and the level between 3 and $10 \mathrm{mg} / \mathrm{L}$ is considered to be high risk for coronary disease. Recent research has shown the clinical significance of C-RP measurement within the normal range which is used for risk assessment of cardiovascular disease, early detection of renal allograft rejection and detection of neonatal infection [11].

In this study we have made an estimation of hs C-RP in normal individuals and in patients with past history of myocardial infarction but are asymptomatic at present. hsC-RP assay is used to estimate C-RP levels between $0.1-15 \mathrm{mg} / \mathrm{L}$. Normal range is $0.068-8.2 \mathrm{mg} / \mathrm{L}[12]$. A strong relationship between CRP level and disability associated with coronary disease has shown by many large observational studies [9,13]. Statins decrease systemic inflammation by decreasing the levels of atherogeneic lipoproteins and thereby reduce C-RP levels. An alternative hypothesis proposes that statins have direct anti inflammatory effects, independent of their lipid lowering capabilities. In this model CRP plays a more direct role in the pathogenesis of atherosclerosis

Coronary Atherosclerosis- Epicardial coronary arteries are the major site of atherosclerotic disease. The major risk factors for atherosclerosis are high plasma LDL, low plasma HDL, cigarette smoking, hypertension, and diabetes mellitus. There are interactions between platelets and monocytes and inappropriate constriction and abnormal luminal clot formation. In different segments of the epicardial coronary tree subintimal collections of cells, fat and debris occurs and this eventually lead to segmental reductions in cross sectional areas (stenosis).

Atherosclerosis is the accumulation of lipoproteins in the blood vessels. Atherosclerotic lesions are asymmetric focal thickenings of the innermost layer of the artery, the intima. They consist of cells, connective tissues elements, lipids and debris. Blood-borne inflammatory and immune cells constitute an important part of an atheroma, the remainder being vascular endothelial and smooth muscle cells. A fatty streak which is accumulation of lipid -laden cells beneath the endothelium occurs before development of atheroma. [14]. Fatty streak consists of macrophages and some Tcells. Fatty streaks never cause symptoms, and may progress to atheromata or eventually disappear.

In the centre of an atheroma, foam cells and extra cellular lipid droplets form a core region, which is surrounded by a cap of smooth- muscle cells and a collagen- rich matrix. T-cells, macrophages, and mast cells infiltrate the lesion and are particularly abundant where the atheroma grows $[11,15,16]$. Many of the immune cells exhibit signs of activation and produce inflammatory cytokines [17].

Myocardial Infarction occurs when the atheromatous process prevents the blood flow through the coronary artery. Angiographic studies identified culprit lesions do not cause marked stenosis [18] and it is now evident that activation of plaque rather than stenosis precipitates ischemia and infarction. Coronary spasm may be involved in some extent, but most cases infarctions are 
due to the formation of an occluding thrombus on the surface of the plaque [19].

A fatty streak represents the initial lesion of atherosclerosis. The formation of these early lesions of atherosclerosis most often seems to arise from focal increases in the content of lipoprotein within regions of the intima. Lipoproteins that accumulate in the extra cellular space of the intima of arteries often associate with proteoglycan molecules of the arterial extra cellular matrix. Lipoproteins particles particularly those bound to matrix macromolecules may undergo chemical modifications. Modifications of lipoproteins occurs in the atheroma which have a pathogenic role. Two types of such alterations in lipoproteins bear particular interest in the context of understanding how risk factors actually promote atherogenesis, oxidation and Nonenzymatic glycation [20].

The present study is aimed for the:

A) Estimation of High sensitivity C-Reactive Protein (HS-CRP) levels in the serum sample of normal people and in patients with past history of myocardial infarction.

B) Estimation of other risk factors of atherosclerosis lipoprotein profile in these serum samples.
Patient Selection- Serum samples were taken from people with history of Myocardial Infarction but without any recent symptoms or signs of any disease including that of the heart disease. LDH is marker of cytosol. When there is tissue injury the plasma membrane is broken and cytosol leaks out of the cell. This results in increase in the level of LDH. The serum samples were selected only if LDH levels were in the normal range. The age matched control samples were selected from normal individuals who do not have any non debilitating disease conditions which may influence hsC-RP levels. Twenty-one control samples and twenty six serum samples from patients who had a history of Myocardial Infarction were included in the study.

Blood Collection- People with apparently no recent history of any symptoms of disease were selected and $5 \mathrm{ml}$ of blood was collected by venous puncture taken in a plain bottle without anticoagulants. The sample was allowed to clot and serum was separated by centrifugation at $3000 \mathrm{rpm}$ for 5 minutes LDH levels were estimated and the samples were discarded if the LDH levels were above normal range.

The lipoprotein profile were estimated by enzymatic method in the fully automated Biochemistry AnalyzerVitros 5,1 FS. High sensivity Creactive protein was done by immunoturibidimetric method. [21]

\section{Results}

The levels of CRP estimated from patients with history of myocardial infarction but who were otherwise apparently normal and in the age matched controls is listed along with the other risk factors of atherosclerosis in (Table1, Figure1). The mean CRP level was $3.385 \mathrm{mg} / \mathrm{L}$ with a SD of 0.53 . The mean was found to be significantly higher than the mean value of $0.845 \mathrm{mg} / \mathrm{L}$ with a $\mathrm{SD}$ of $0.25 \mathrm{seen}$ in age matched controls. Total cholesterol and LDL cholesterol are significantly increased in patients who had myocardial infarction (Table1,Figure 2)

Table 1: Comparison of concentration of hs-CRP and other risk factors of atherosclerosis in patients who had history of M.I. and in age matched controls.

\begin{tabular}{|l|l|l|l|l|}
\hline & $\begin{array}{l}\text { Control mean } \\
\pm \text { SD }\end{array}$ & $\begin{array}{l}\text { Patient mean } \\
\pm \text { SD }\end{array}$ & t-value & P-value \\
\hline hsCRP & $0.845 \pm 0.25$ & $3.385 \pm 0.53$ & 3.12 & $\mathrm{P}<0.01$ \\
\hline TC & $153.07 \pm 35.12$ & $204.93 \pm 45.01$ & 3.78 & $\mathrm{P}<0.001$ \\
\hline TG & $98.88 \pm 48.64$ & $118.6 \pm 25.21$ & 0.6 & $\mathrm{P}>0.05$ \\
\hline HDL & $26.76 \pm 8.82$ & $45.13 \pm 6.89$ & 6.1 & $\mathrm{P}<0.001$ \\
\hline LDL & $134.46 \pm 30.18$ & $142.4 \pm 30.39$ & 3.86 & $\mathrm{P}<0.001$ \\
\hline VLDL & $23.6 \pm 4.67$ & $19.76 \pm 5.1$ & 1.84 & $\mathrm{P}<0.1$ \\
\hline
\end{tabular}




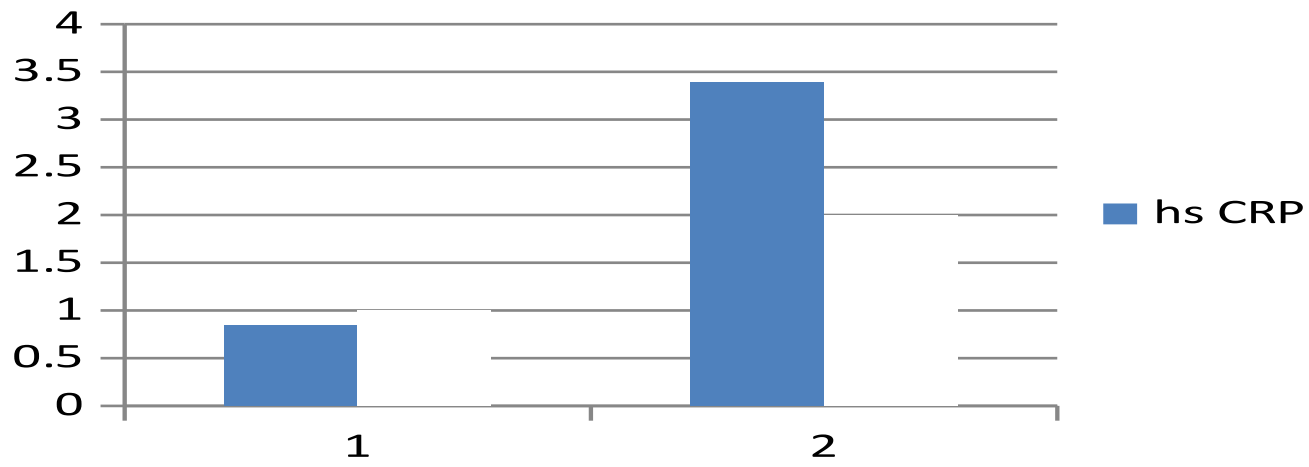

Figur 1: Hs CRP levels in normal persons and those who had previous history of MI

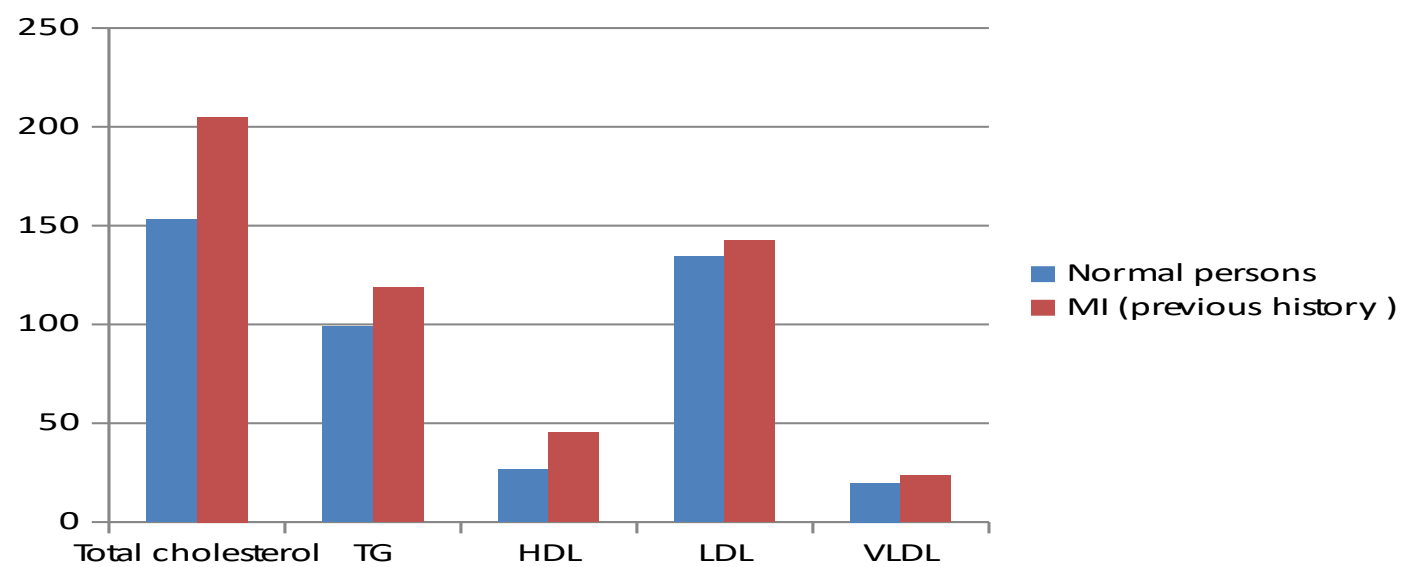

Figure-2: Lipoprotein values in normal persons and those who had previous history of MI

\section{Discussion}

Few studies have also done to investigating the role of C-reactive protein and interleukin-6 soluble tumour necrosis factor alpha $(\mathrm{TNF}-\alpha)$ receptors type $1 \& 2$ (sTNF-R1 and sTNF-R2) as predictors of cardiovascular events. Inflammation plays an essential role in the initiation and progression of atherosclerotic lesions and plaque disruption [22]. Interleukin-6 and tumour necrosis factor $\alpha$ (TNF- $\alpha$ ) are inflammatory cytokines which are the main inducers of the secretion of $\mathrm{C}$ reactive protein in the liver. C-RP has a role in the progression of atherosclerosis. In their study the C-RP was determined by means of a highly sensitive immunoturbidimetric assay. They categorized the study participants on the basis of recently proposed cut off points for CRP, as having low levels less than $1.0 \mathrm{mg} / \mathrm{L}$ moderate levels $1.0-2.9 \mathrm{mg} / \mathrm{L}$ and higher levels at least
$3.0 \mathrm{mg} / \mathrm{L}$ [23]. They found that high plasma levels of CRP were associated with an increased risk of coronary heart disease among women and men without previous history of cardiovascular diseases. Their study indicated that increased levels of hs C-RP are associated with an increased risk of coronary heart disease. They also concluded that the risk of coronary heart disease depends on level of hS C - RP . In our study hs C-RP level is significantly higher than those of control sample. The total cholesterol, HDL cholesterol and LDL cholesterol levels are also significantly elevated in individuals who had previous history of myocardial infarction. A previous meta analysis of studies published before 2000 reports an odds ratio for coronary heart disease of about 2.0. Their findings suggest that recent recommendations regarding the use of measurements of $\mathrm{C}$-reactive protein in the prediction 
of coronary heart disease may need to be reviewed [24]. They opined that $\mathrm{C}$ reactive protein can moderately predict coronary heart disease.

Earlier trials have also been demonstrated better outcomes with intensive than with moderate statin treatment. The intensive treatment produced greater reductions in both low-density lipoprotein (LDL), cholesterol and C-reactive protein (CRP), suggested a relationship betweenthese two biomakers and disease progression. The two recent trials demonstrated that there is an intensive lipid-lowering therapy with statins which improved the clinical outcomes and reduced the progression of atherosclerosis [25]. As compared with moderate statin therapy with intensive treatment there is a great reductions in the levels of atherogenic lipoproteins, particularly low-density lipoprotein (LDL) cholesterol and proportionally decreased cardiovascular risk. [30, 31] By large observational studies they concluded that there is a strong relationship between CRP levels and the morbidity associated with coronary diseases $[8,13]$.

\section{Conclusion}

Inflammation plays an important role in myocardial infarction. Increased levels of hsC-RP are associated with increased risk of MI even when the lipid levels are normal. Coronary artery disease may be prevented by reducing the inflammation in addition to reducing the LDL cholesterol levels.

Funding: Nil, Conflict of interest: None.

Permission of IRB: Yes

\section{References}

1. Albert MA, Ridker PM. C-reactive protein as a risk predictor: do race/ethnicity and gender make a difference? Circulation. 2006 Aug 1;114(5):e67-74.

2. Willerson JT, Ridker PM. Inflammation as a cardiovascular risk factor. Circulation. 2004 Jun 1;109(21 Suppl 1):II2-10

3. Hansson GK. Inflammation, atherosclerosis, and coronary artery disease. N Engl J Med. 2005 Apr 21;352(16):1685-95.

4. Liuzzo G, Biasucci LM, Gallimore JR, Grillo RL, Rebuzzi AG, Pepys MB, Maseri A. The prognostic value of C-reactive protein and serum amyloid a protein in severe unstable angina. N Engl J Med. 1994 Aug $18 ; 331(7): 417-24$
5. Lindahl B, Toss H, Siegbahn A, Venge P, Wallentin L. Markers of myocardial damage and inflammation in relation to long-term mortality in unstable coronary artery disease. FRISC Study Group. Fragmin during Instability in Coronary Artery Disease. N Engl J Med. 2000 Oct 19;343(16):1139-47.

6. Liuzzo G, Biasucci LM, Rebuzzi AG, Gallimore JR, Caligiuri G, Lanza GA, Quaranta G, Monaco C, Pepys $\mathrm{MB}$, Maseri A. Plasma protein acute-phase response in unstable angina is not induced by ischemic injury. Circulation. 1996 Nov 15;94(10):2373-80.

7. Danesh J, Wheeler JG, Hirschfield GM, Eda S, Eiriksdottir G, Rumley A, Lowe GD, Pepys MB, Gudnason V. C-reactive protein and other circulating markers of inflammation in the prediction of coronary heart disease. N Engl J Med. 2004 Apr 1;350(14):138797.

8. Ledue TB, Rifai N. Preanalytic and analytic sources of variations in C-reactive protein measurement: implications for cardiovascular disease risk assessment. Clin Chem. 2003 Aug;49(8):1258-71.

9. Ridker PM, Rifai N, Rose L, Buring JE, Cook NR. Comparison of $\mathrm{C}$-reactive protein and low-density lipoprotein cholesterol levels in the prediction of first cardiovascular events. N Engl J Med. 2002 Nov 14;347(20):1557-65.

10. Pai JK, Pischon T, Ma J, Manson JE, Hankinson SE, Joshipura K, Curhan GC, Rifai N, Cannuscio CC, Stampfer MJ, Rimm EB. Inflammatory markers and the risk of coronary heart disease in men and women. $\mathrm{N}$ Engl J Med. 2004 Dec 16;351(25):2599-610.

11. Stary HC, Chandler AB, Dinsmore RE, Fuster V, Glagov S, Insull W Jr, Rosenfeld ME, Schwartz CJ, Wagner WD, Wissler RW. A definition of advanced types of atherosclerotic lesions and a histological classification of atherosclerosis. A report from the Committee on Vascular Lesions of the Council on Arteriosclerosis, American Heart Association. Circulation. 1995 Sep 1;92(5):1355-74.

12. Ridker PM, Hennekens CH, Buring JE, Rifai N. Creactive protein and other markers of inflammation in the prediction of cardiovascular disease in women. $\mathrm{N}$ Engl J Med. 2000 Mar 23;342(12):836-43. 
13. Ridker PM. Clinical application of C-reactive protein for cardiovascular disease detection and prevention. Circulation. 2003 Jan 28;107(3):363-9.

14. Stary HC, Chandler B, Glagov S, et al., A definition of initial, fatty streak, and intermediate lesions of atherosclerosis: a report from the committee on vascular lesions of the council on Atherosclerosis, American Heart Association. Circulation. 1994; 89: 2462 - 78.

15. Jonasson L, Holm J, Skalli O, Bondjers G, Hansson GK. Regional accumulations of $\mathrm{T}$ cells, macrophages, and smooth muscle cells in the human atherosclerotic plaque. Arteriosclerosis. 1986 Mar-Apr;6(2):131-8.

16. Kovanen PT, Kaartinen M, Paavonen T. Infiltrates of activated mast cells at the site of coronary atheromatous erosion or rupture in myocardial infarction. Circulation. 1995 Sep 1;92(5):1084-8.

17. Davies MJ. Stability and instability: two faces of coronary atherosclerosis. The Paul Dudley White Lecture 1995. Circulation. 1996 Oct 15;94(8):2013-20.

18. Smith JD, Trogan E, Ginsberg M, Grigaux C, Tian J, Miyata M. Decreased atherosclerosis in mice deficient in both macrophage colony-stimulating factor (op) and apolipoprotein E. Proc Natl Acad Sci U S A. 1995 Aug 29;92(18):8264-8.

19. Peiser L, Mukhopadhyay S, Gordon S. Scavenger receptors in innate immunity. Curr Opin Immunol. 2002 Feb;14(1):123-8.

20. Mortensen ES, Fenton KA, Rekvig OP. Lupus nephritis: the central role of nucleosomes revealed. Am J Pathol. 2008 Feb;172(2):275-83. doi: 10.2353/ajpath.2008.070563. Epub 2008 Jan 10

21. Procedure manual Vitros 5,1 FS

22. Libby P. Inflammation in atherosclerosis. Nature. 2002 Dec 19-26;420(6917):868-74.
23. Pearson TA, Mensah GA, Alexander RW, et al., Markers of inflammation and cardiovascular disease: application to clinical and public health practice: a statement for health care professional from the centers for Disease Control and Prevention and the American Heart Association. Circulation. 2003; 107: 499-511.

24.Pearson TA, Mensah GA, Alexander RW, et al., Markers of inflammation and cardiovascular disease: application to clinical and public health practice:a statement for healthcare professionals from the centers for disease control and prevention and the American Heart association. Circulation 2003; 107: 499- 511.

25.Nissen SE, Tuzcu EM, Schoenhagen P, Brown BG, Ganz P, Vogel RA, Crowe T, Howard G, Cooper CJ, Brodie B, Grines CL, DeMaria AN; REVERSAL Investigators. Effect of intensive compared with moderate lipid-lowering therapy on progression of coronary atherosclerosis: a randomized controlled trial. JAMA. 2004 Mar 3;291(9):1071-80.

26. Sacks FM, Pfeffer MA, Moye LA, Rouleau JL, Rutherford JD, Cole TG, Brown L, Warnica JW, Arnold JM, Wun CC, Davis BR, Braunwald E. The effect of pravastatin on coronary events after myocardial infarction in patients with average cholesterol levels. Cholesterol and Recurrent Events Trial investigators. $\mathrm{N}$ Engl J Med. 1996 Oct 3;335(14):1001-9.

27. Sever PS, Dahlöf B, Poulter NR, Wedel H, Beevers G, Caulfield M, Collins R, Kjeldsen SE, Kristinsson A, McInnes GT, Mehlsen J, Nieminen M, O'Brien E, Ostergren J; ASCOT investigators. Prevention of coronary and stroke events with atorvastatin in hypertensive patients who have average or lower-thanaverage cholesterol concentrations, in the AngloScandinavian Cardiac Outcomes Trial--Lipid Lowering Arm (ASCOT-LLA): a multicentre randomised controlled trial. Lancet. 2003 Apr 5;361(9364):1149-58.

\section{How to cite this article?}

Sindu P.C. High Sensitivity C-Reactive Protein an inflammatory marker and lipoprotein levels in patients with coronary heart disease : Int J Med Res Rev 2016;4(3):444-449. doi: 10.17511/ijmrr.2016.i03.28. 